\title{
DUCKS AND TRUCKS. TRACKING THE ORIGIN OF WATER-BIRDS AND CHARIOTS OF PRE-ROMAN DACIA
}

\begin{abstract}
The subject of this paper is related with some solar and celestial representation discovered in the intra-Carpathian space dated from the Late Iron Age. The paper will focus on water-birds protomes discovered at Sarmizegetusa Regia and Costești-„,Cetățuie”, water-birds shaped handles on some situlae handles and other birds' representation. As well the study will focus on the association of this water-bird representation with wheels or chariots and some vessels. The research is not concerned only on discussion of the symbolism of this group of representation, but as well on understanding the origins and how the idea travelled from one community to other and finally reach the space lived by Dacian communities..
\end{abstract}

Keywords: water-birds, wheel, wagon-model, Late Iron Age, pre-Roman Dacia.

olar symbols as water-birds and wheel/chariot are symbols that travelled through time and space and can be encountered at almost each cultural environment. The symbolism of the wheel, either as votive offering inside of sanctuary or temples or as funerary good, is associated with the disk of the sun in many cultural spaces or timeframes, giving by the similarities of wheel and sun, the movement of both and the common motif of a solar chariot moving across the sky ${ }^{1}$. Water-birds are usually associated with the solar cycle of season due to birds' migration to South but as well with the Hyperborean myth of Apollo and the chariot driven by swans. As well, water-birds in association with wheel/chariot and vessel were interpreted in connection with the travel of the dead to the outer world. This symbolic association furnish the evidence for a continued use from Bronze Age to Early Iron Age and furthermore for the long survival of the cult ${ }^{2}$. This paper will try to evidence if this type of association of symbols can be tracked down until Late Iron Age in the intra-Carpathian area; the space lived by Dacian civilization until the roman conquest.

Some water-birds representations were discovered in the Dacian milieu on some situla handles, belts buckles, brooches, lime-stone fragments or painted pottery. If some of above mention artefacts are imported, others are produced by local craftsmen of unknown origin. Nevertheless, the preference for this kind of representations indicates most likely their association with a symbolic signification.

Some of the most intriguing artefacts representing water-birds are the protomes discovered in the Dacian fortress from Costești-Cetățuie (jud.

1 KIRENAN 2009, 24; DIMA/BORANGIC 2018, 28.

2 PARE 1989, 97; PARE 1992, 181-183.

\section{Cristian DIMA}

National History Museum of Transylvania, Cluj-Napoca dimav.cristian@yahoo.com

DOI: $10.14795 / J . V 7 I 1.505$

ISSN $2360-266 \mathrm{X}$

ISSN-L 2360 - 266X 


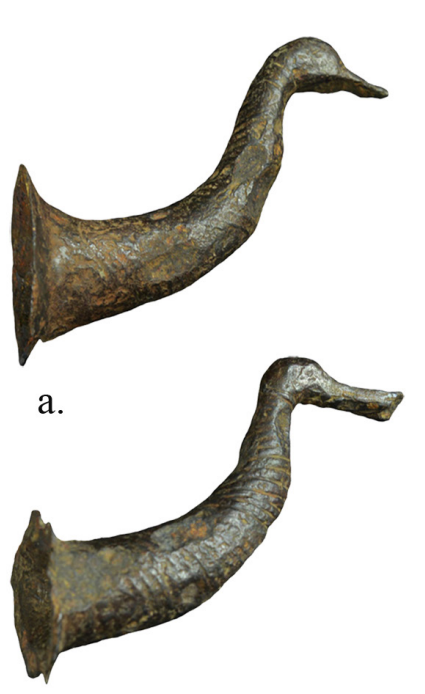

b.

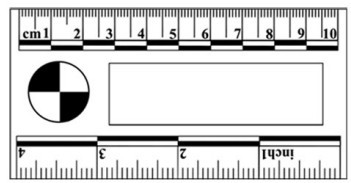

Fig. 1. Water-birds protomes Costești-Cetățuie (after FLOREA 2015) discovered in dacian fortification of

Hunedoara/RO) (Fig. 1/a-b) and Sarmizegetusa Regia - Grădiștea de Munte (jud. Hunedoara/ $\mathrm{RO})^{3}$. In the moment of their publication there were no known data to indicate their functionality and were interpreted either as vessel handles ${ }^{4}$ or, later, as wagon parts ${ }^{5}$. Even it is a big chronological gap, these artefacts as are very similar in shape and size with the ones from Bujoru (jud. Teleorman/RO) chariot especially (Fig. 6/b) ${ }^{6}$, and also with the ones from Orăstie (jud. Hunedoara/RO) (Fig. 6/a) ${ }^{7}$.

However, even that the presence of miniaturised modelwagons in Late Iron Age was recently discussed ${ }^{8}$, it is still difficult to consider that water-birds protomes were part of a model-wagon. The lack of this kind of modelwagons in the Late Iron age in other parts than intraCarpathian space made difficult a research to track down the origins of this type of artefact. As weel, the model-wagons of Dacian milieu are mostly in fragmentary state as the ones coming from the Dacian fortress Luncani-Piatra Roșie ${ }^{9}$ (jud. Hunedoara/Romania) (Fig. 2/a,c); the model-wheel fragment from the Dacian fortress of Piatra Craivii ${ }^{10}$ (jud. Alba/RO); another wheel coming from the Dacian settlement of Sighișoara - "Wietenberg" ${ }^{11}$ (jud. Mureș/RO) (Fig. 2/b); and only the last one, represents an almost entire wagon model, from a Dacian settlement in Miercurea Sibiului ${ }^{12}$ (jud. Sibiu/RO) (Fig. 3).

The most appropriate analogy for Dacian modelwagons was found Macedonian necropolis ${ }^{13}$ in Sindos (per. Thessaloniki/GR $)^{14}$, Archontiko (per. Pella/GR) ${ }^{15}$, Vergina

\footnotetext{
${ }^{3}$ IAROSLAVSCHI 1997, 511-519.

4 IAROSLAVSCHI 1997, 513.

FLOREA 2015, 18-20; FLOREA/CRISTESCU 2016, 146, Fig. 12.

${ }^{6}$ MOSCALU/BEDA 1988, 26; PARE 1992, 181, 184, Fig. 126; VULPE 2001, 44, Fig. 28.

7 HOREDT 1964, 124, Fig. 1; PARE 1992, 181, 184, Fig. 125; SCHUSTER $2007,33$.

8 DIMA/BORANGIC 2018, 15-32.

9 DAICOVICIU 1954, 89, Pl. XV/Fig. 2; DIMA/BORANGIC 2018, 16, Fig. $1 / \mathrm{a}, \mathrm{e}$.

10 Inf. C. Plantos; DIMA/BORANGIC 2018, 16.

11 HOREDT/SERAPHIN 1971, 84, Fig. 67/5; DIMA/BORANGIC 2018, 16, Fig. 1/d.

${ }_{12}$ LUCA et alii 2013, 68; NATEA 2016, 76-78, Pl. 16-17; DIMA/BORANGIC

2018, 17, Fig. 2.

${ }_{13}$ DIMA 2020.

14 THEODOSIEV 2000, 188-191; MANAKIDOU 2010, 177-197; DEL SOCORRO 2013, 53-59.

15 DEL SOCORRO 2013, 15.
}

(per. Imathia/GR) ${ }^{16}$, Pydna (per. Pieria/GR) ${ }^{17}$, Michalitsi (per. Epirus/GR) ${ }^{18}$. Edessa(per. Pella/GR) ${ }^{19}$, Gorna Porta (opš. Ohrid/MK) ${ }^{20}$. The graves in which cart-models were placed are dated from the $6^{\text {th }}$ and 4 th century BC when they cease being deposited in the Macedonian necropolis, the last surviving example being represented at Pydna, tomb 45 , which is larger than the others, but without reaching the dimensions of a life-size on $\mathrm{e}^{21}$. The model carts from Macedonian necropolises are two-wheeled with a higher box in the case of male tombs, while for the female graves are present the four-wheeled wagons with biers ${ }^{22}$. Twowheeled chariots were associated with Dionysiac and Eleusinian celebration in Attic iconography, while the fourwheeled wagons were associated with the deceased's funeral procession $^{23}$. Additionally, the gender differentiation of the miniature wagon deposition in tombs was explained by differences between male and female main occupations, while with the four-wheeled wagon is used for agriculture labour, the domain of women, while the two-wheeled chariots having a military role, a field of the men ${ }^{24}$. These miniature wagons were considered as symbol of funeral carts depicted later on Thracian monuments ${ }^{25}$, but likely are related as well with the presence of ceremonial chariots in Thracian necropolis as an entire funeral ritual. As well, the presence of miniaturised carts in graves was interpreted as substituents for the real ones and could be associated with passage rites and beliefs about afterlife ${ }^{26}$.

Some graves from Sindos ${ }^{27}$, Archontiko ${ }^{28}$ or Vergina ${ }^{29}$ containing different objects are placed in relation with priesthood. The placing of such cult objects in the graves suggest a specific status, both religious and royal that can be referred to as priestly or royal-priestly ${ }^{30}$, the presence of both miniature chair and table being associated with priesthood ${ }^{31}$. This graves also contained miniature carts which were interpreted in the case of women grave, as well, as proof of showing the right to appear in public and take part in ritual procession and ceremonies ${ }^{32}$. These traditions, followed by the women of the Temenid Kingdom have roots in religious manifestation and the status of women in the earlier period of $9^{\text {th }}-6^{\text {th }}$ century BC. The graves of women belonging to the Early Iron Age Macedonian necropolises contain rich inventories that also provide evidence for their royal and

\footnotetext{
${ }^{16}$ THEODOSIEV 2000, 188-191; MANAKIDOU 2010, 177-197; DEL SOCORRO 2013, 53-59.

17 THEODOSIEV 2000, 188-191; MANAKIDOU 2010, 177-197; DEL SOCORRO 2013, 53-59.

18 THEODOSIEV 2000, 188-189; DASEN 2012, 14.

19 DEL SOCORRO 2017, 115

20 VON WOLFGANG 2014, 48

${ }^{21}$ DEL SOCORRO 2017, 110.

22 BOUZEK/ONDŘEJOVÁ 1988，93; IGNATIODOU 2012，398; DEL SOCORRO 2013,56

${ }^{23}$ IGNATIODOU 2012, 398.

24 DEL SOCORRO 2017, 166

25 BOUZEK/ONDŘEJOVÁ 1988, 93; cf. VENDIKOV/GHERASIMOV 1973, Fig. 56.

${ }^{26}$ CHRYSOSTOMOU/CHRYSOSTOMOU 2012, 372-373.

27 IGNATIODOU 2012, 388-411.

${ }^{28}$ CHRYSOSTOMOU/CHRYSOSTOMOU 2012, 366-387.

29 KOTTARIDI 2004, 139-147.

30 GERGOVA 2006, 52.

${ }^{31}$ IGNATIODOU 2012, 397

32 KOTTARIDI 2011, 97.
} 

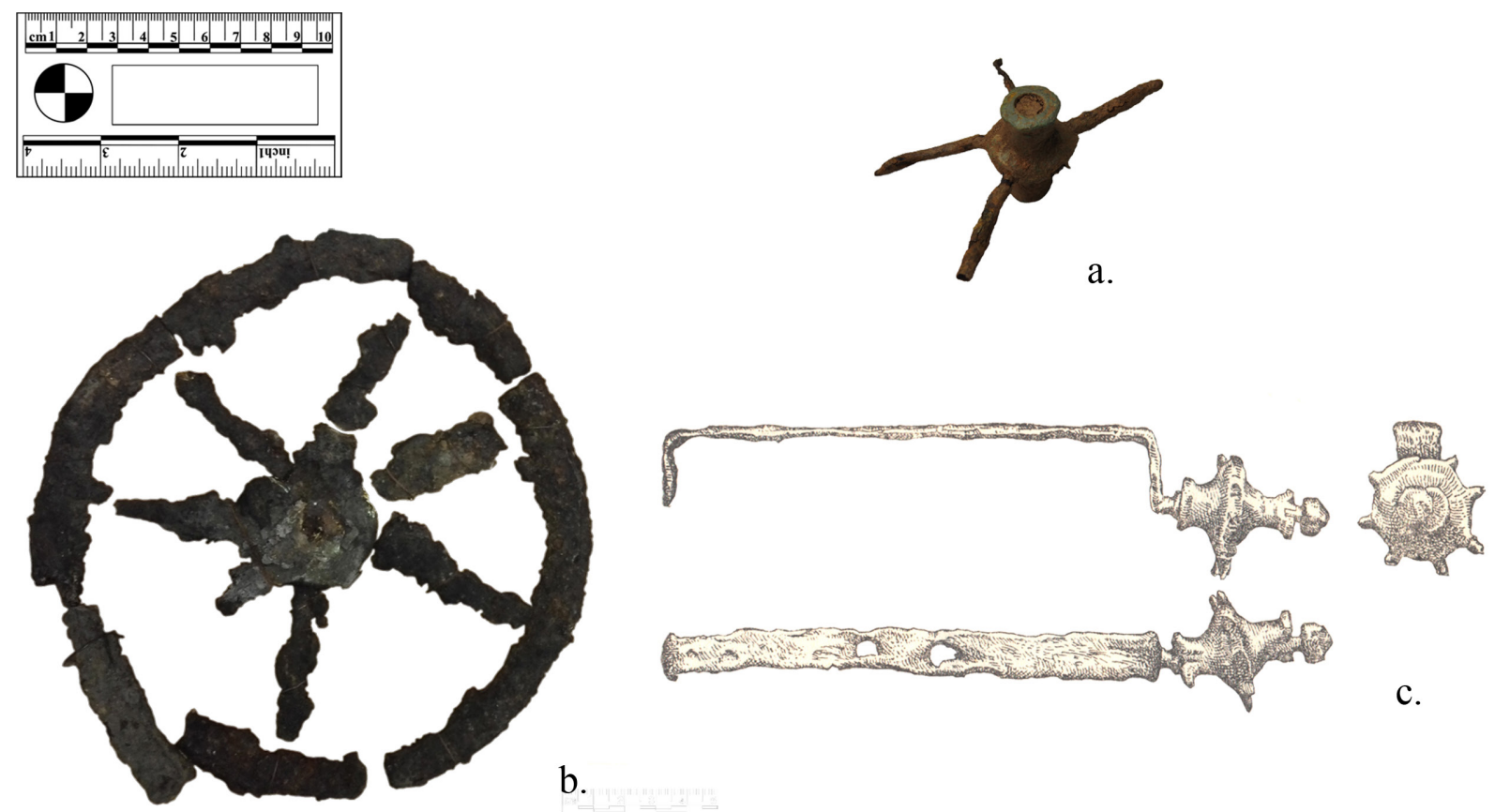

Fig. 2. Model-wheels and miniatural wheels in form of: a. Luncani-Piatra Rosie; b. Sighisoara-Wietemberg (after Horedt/Seraphin 1971, Fig. 63/2); c. Luncani-Piatra Roșie. (after Daicoviciu 1954, p. 89, Pl. XV, Fig. 2.).

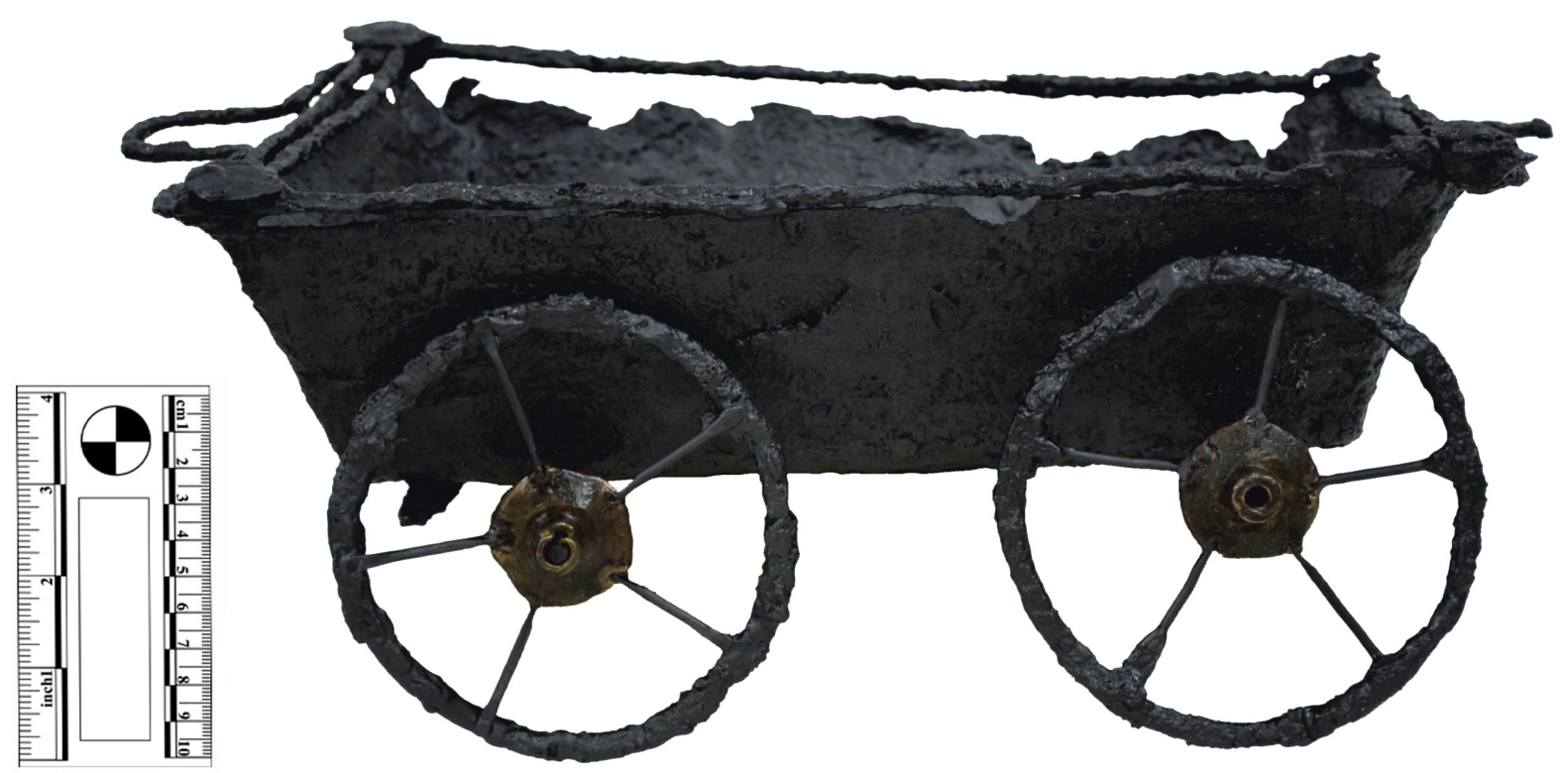

Fig. 3. Model-wagon: Miercurea Sibiului (after NATEA 2016).

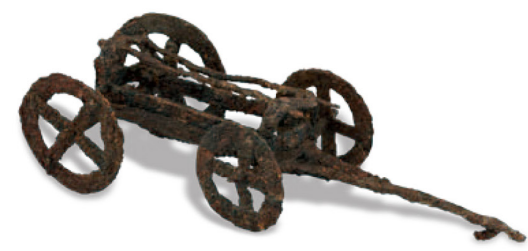

a.

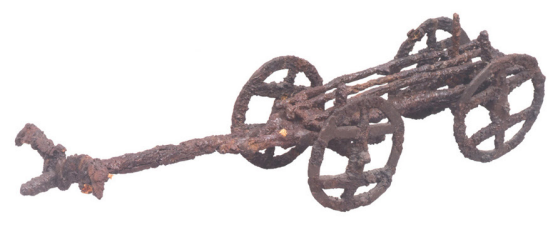

b.

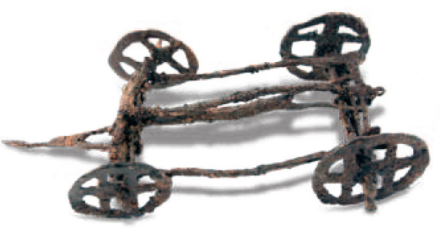

c.

Fig. 4. Cart models from Macedonian graves: a. Sindos (after IGNATIODOU 2012, 410, 37); b. Vergina (after KOTTARIDI 2011, Fig. 88); Archontiko (after CHRYSOSTOMOU/CHRYSOSTOMOU 2012, Fig. 14). 

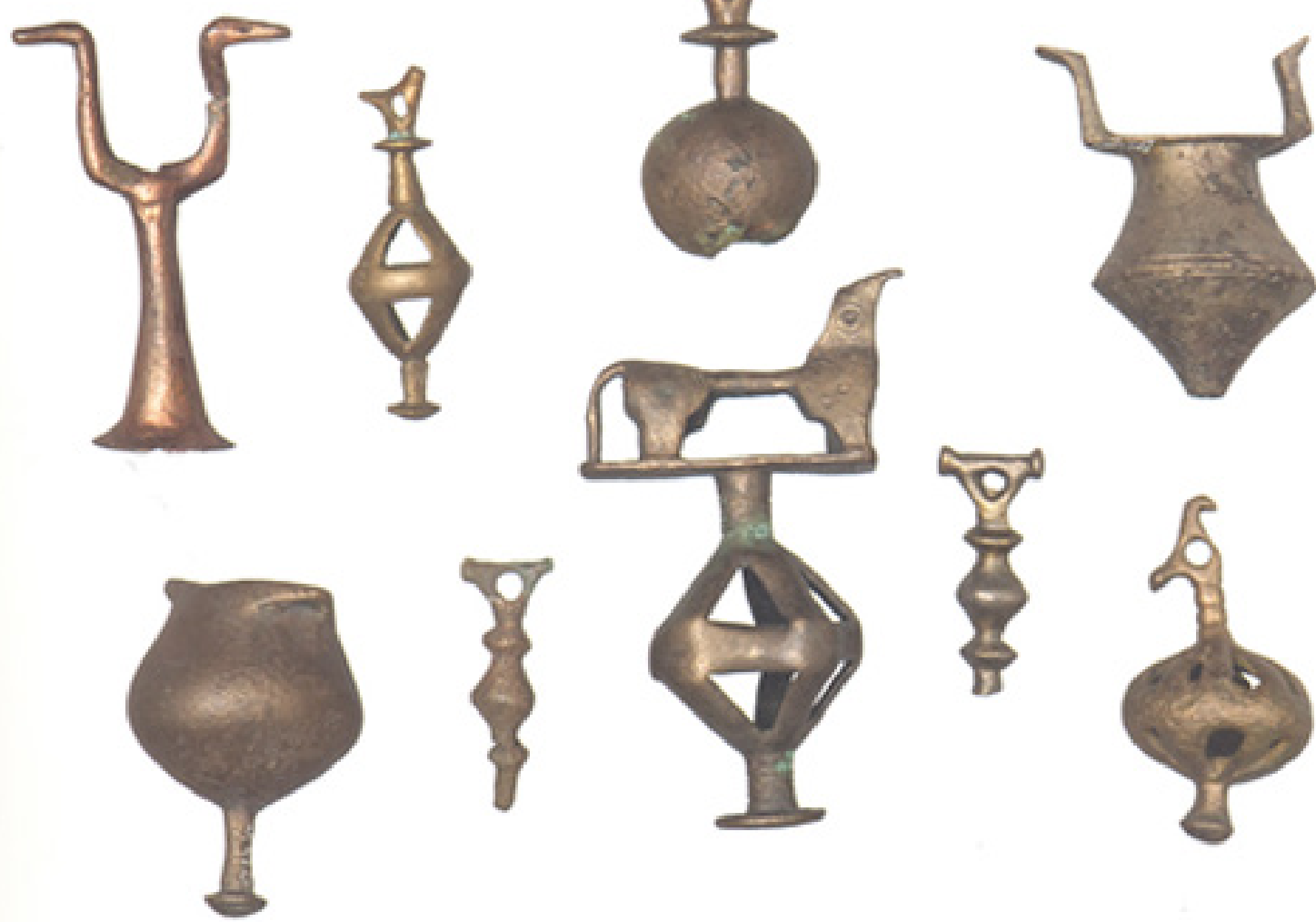

Fig. 5. Water-birds pyxix pendants (after KOTTARIDI 2011).

religious status. The graves of these rich women contained other elements to suggest the social status and appurtenance to priesthood or royal-priesthood such as bronze triple or double axes associated with sacrificial rituals, diadems with solar symbols, miniature four-spoked wheels and pyxix pendants, some of them with water-bird protomes ${ }^{33}$. The pyxix pendants with water-bird protomae were placed in female graves and interpreted as recipients for remedies and herbs (Fig. 5). The water-birds in form of pendants or pyxis pendants are linked to the production of Macedonian bronzes. The feature of bird protomes of the Macedonian pyxis pendants were widespread in ancient Europe, usually in antithetic pairs and spread from there to Greece by the end of the Mycenaean period. These Macedonian bronzes carry on from an older tradition, related to sub-Mycenaean jewellery in Greece and emanating from the same European tradition of the Late Tumulus and early Urnfield cultures ${ }^{34}$. The small symbolic four-spoked wheels placed in Macedonian graves have their ancestral forerunners in the Vergina cemetery with several examples being also found in Greece, but also very common in the Urnfield and Hallstat ornaments of prehistoric Europe ${ }^{35}$. The use of symbolic combination of wheel, vessel and waterbird is illustrated by the Macedonian and Thesalian pyxis pendants belonging to Early Iron Age and the Kesselwagen from Delphi in the $8^{\text {th }}$ and $7^{\text {th }}$ century BC

\footnotetext{
${ }_{33}$ KOTTARIDI 2011, 97.

${ }^{34}$ BOUZEK 1974, 25, 183.

${ }_{35}$ BOUZEK 1974, 140.
}

and provides a link between earlier Kesselewagen of Urnfield period and those of the Villanovan and Hallstatt cultures ${ }^{36}$.

The Bronze Age wagon models belonging to the Urnfield culture are known as vessel-carrying wagon models (Kesselwagen) provided as grave goods, within the vessel being carried the cremated remains of the deceased. Some of these wagons have water-birds protomes and were found in Acholshausen (Lkr. Würzburg/D), Peckatel (Lkr. LudwigslustParchim/D), Skallerup (Morsø Kom./DK), Milavče (okr. Domažlice/CZ) ${ }^{37}$. The appearance of the Kesselwagen graves in the same period with the life-size wagon-graves of Bronze Age is related to the arrival of new religious beliefs involving a complex of symbols, including water-bird protomes, wheel symbols and lancet, hourglass and double-axe motifs which formed the start of Urnfield period ${ }^{38}$. This developed later in the Villanovan and Hallstatt cultures of the Early Iron Age in different parts of Europe, mainly rity in Italy, also related with funerary practice39. These kinds of wagon were also found in the Carpathian Basin, some of them being shaped in the shape of water birds as the one from Glasinac (opš. Sokolac/ BA) 40 (Fig. 6/c) but also the Kesselwagen represented with antithetic water birds like the Basarabi culture wagon from Bujoru $^{41}$ (Fig. 6/b) or the ones discovered in Orăștie (jud.

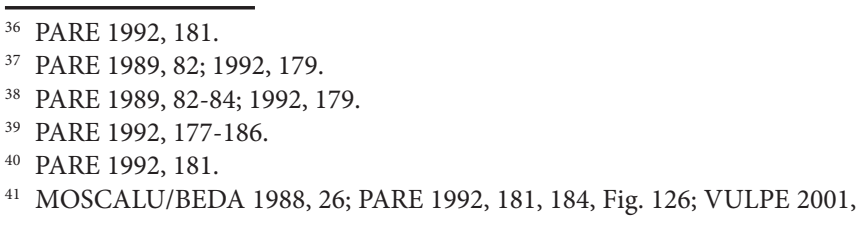



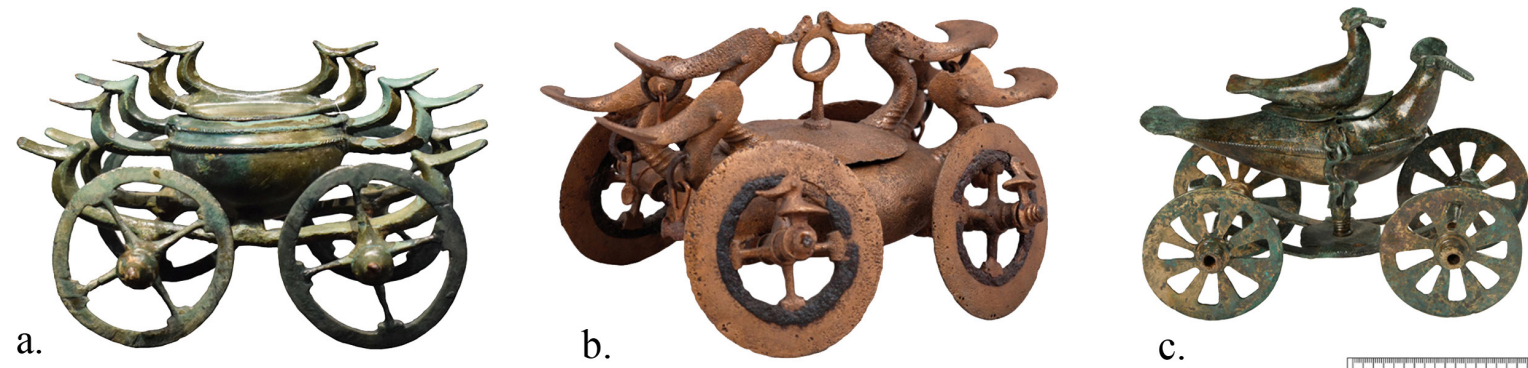

c.

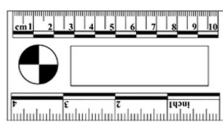

Fig. 6. Early Iron Age model-wagons with water-birds protomes: a. Orăștie (photo C. Dima); b. Bujoru (photo C. Borș); c. Glasinac (photo C. Dima)

Hunedoara/RO ${ }^{42}$ (Fig. 6/a) and Dephi ${ }^{43}$.

The symbolism of the wheel, either as votive offering inside of sanctuaries or temples or as funerary good, is associated with the disk of the sun in many cultural spaces or timeframes given the similarities of wheel and sun, the movement of both and the common motif of a solar chariot moving across the sky are the basic ideas behind this ${ }^{44}$. Also, one may noticed a strong connection for the chariots belonging to the First Age of Iron, and Late Bronze Age, with a solar cult. The presence of water-birds on many Kesselwagens, and together with other types of wagons, has an important significance in the journey of the dead to the other world, but also it represents a prime importance in understanding the meaning and origins of the idea. The symbolic association between wagon, vessel and water birds of the cult wagon models from Delphi, Orăștie and Bujoru, betrays a relationship to the Macedonian-Thesalian pyxis pendant and associated four spoked-wheels. This supports the evidence for a continued use of this kind of wagons from the Bronze Age to Hallstatt period and furthermore for the long survival of the cult ${ }^{45}$. However, the Kesselwagen from Delphi was placed in the sanctuary of Apollo, not in a funerary context as the other ones and this may suggest a dissolute message that was continued in different forms. This symbolism continued in some of the Macedonian Graves of the Temenid Kingdom where the wheel is not only represented as part of miniature carts but as well as on golden masks, diadems, helmet ornamentation etc ${ }^{46}$ represented as solar symbol present as well on bronze diadems or vessel of earlier period ${ }^{47}$. The water-birds are present in several graves in different forms, but with the antithetic water-birds just in only a few cases and in relation with vessels used for libation or banquet. The vessels are present in the Macedonian graves with cart-models, some of them used for cremated remains, mostly in the case of rich male graves; women being all interred at least until $5^{\text {th }}$ century $\mathrm{BC}^{48}$. Others contained

\footnotetext{
44, Fig. 28.

${ }^{42}$ HOREDT 1964, 124, Fig. 1; PARE 1992, 181, 184, Fig. 125; SCHUSTER 2007, 33.

${ }_{43}$ PARE 1992, 181, 184, Fig. 124.

${ }^{44}$ KIRENAN 2009, 34.

45 PARE 1989, 97; PARE 1992, 181-183.

${ }^{46}$ THEODOSIEV 2000, Fig. 12-13; KOTARIDI 2004, 143; CHRYSOSTOMOU/ CHRYSOSTOMOU 2012, Fig. 5.

${ }^{47}$ KOTTARIDI 2011, Fig. 84.

${ }^{48}$ KOTTARIDI 2004, p. 142.
}

wine used for libation and funerary banquet.

Even that beginning with $6^{\text {th }}$ century $B C$ there are no Kesselwagen with antithetic birds, the concept of „vesselbearing wagon" and the „vessel with antithetic birds-pair” seems to have been surviving at least until the $3^{\text {rd }}$ century $\mathrm{BC}$ in the Balkans in the customs of the Thessalian city of Crannon (per. Larissa/GR). The custom, recorded by Antigonos Carystos, referrers to a sacred bronze wagon, which was set in motion in times of drought, a cult practice associated also with two sacred ravens. These two symbols (the wagon and the pair of ravens) formed the parasemnon of the city of Carnnon, represented also on city coins ${ }^{49}$.

The symbol of antithetic birds and the sun is attested in many other civilisations and it has roots in the ideology brought to Europe by the Urnfiled culture bearers. This kind of iconography spreads in time and space, but very often the concept transmitted is dissolute, variated or re-adapted. In many cases the water-birds were replaced with birds of prey as in the case of Carannon customs where the antithetic birds are raven, but the significance for the city of Carannon is not necessarily to be the same for the Urnfield culture bearers. In Macedonian graves a few golden ornaments have representation of two birds of prey framing an eightpetal rosette ${ }^{50}$. This motif was perpetuated through time and reinterpreted and could be seen as well in the warriors of the group Padea-Panagjurski Kolonii group, the birds of prey confronting each other with a sun in the middle being a common motif represented on their dagger (sicae).

The wagon models from Macedonian cemeteries were often associated with other miniaturised goods as chairs, tables and obeloi, and could be interpreted together as an ensemble, even though not all the elements are present in every tomb $b^{51}$. This kind of assemblage was placed in relation to the funerary banquet, organised in honour of the deceased by his family and the participants that were seated on chairs ${ }^{52}$. The miniatures found in Macedonia were interpreted as an indication that the ones attending the banquet are seated on chairs, thus having parallels with the fresco found in Kazanlak (Stara Zagora okr./BG) chambered tomb in Thrace where banqueters sit on chairs ${ }^{53}$, but also

\footnotetext{
${ }_{99}$ PARE 1989, 97, Fig. 17; PARE 1992, 185, Fig. 127.

${ }^{50}$ THEODOSIEV 2000, 197-199.

1 DEL SOCORRO 2017, 168.

52 DEL SOCORRO 2017, 169

${ }^{53}$ DEL SOCORRO 2017, 169 .
} 


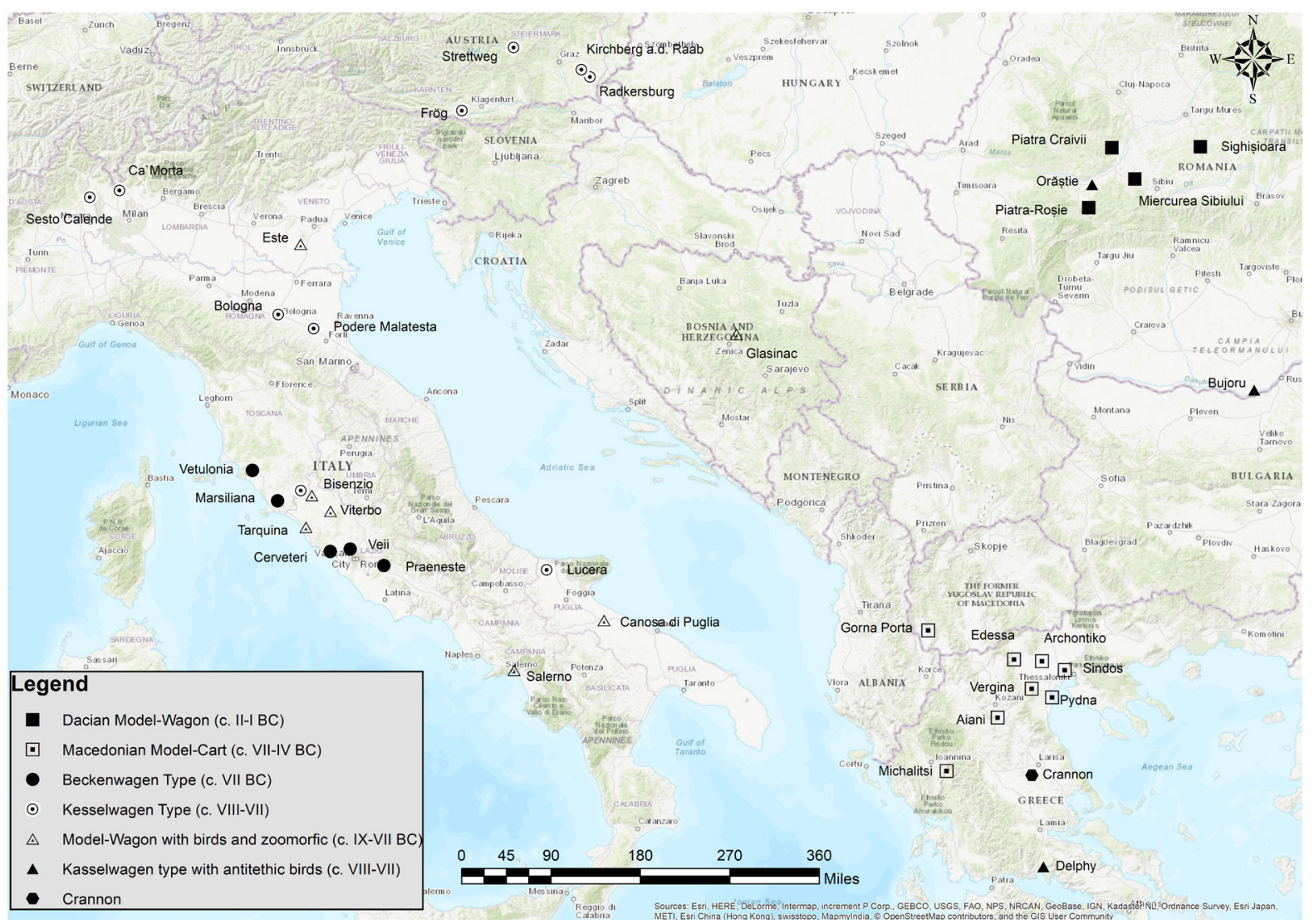

Fig. 7. Map of wagon-models distribution in different chronological frames.

with other similar practices attested in ancient Thrace ${ }^{54}$.

The presence of miniature chariots in Macedonian necropolises represents an image of the life-size cart used for the transport of the deceased in the ritual procession of ekphora, a custom well attested in Geometric and Archaic Greek painting and even a terracotta model of a cart dated to the $7^{\text {th }}$ century BC from a burial at Vari (per. Attica/GR) ${ }^{55}$. The carrying of the dead in a chariot is well attested in other civilisations, sometimes the life-size chariot being buried with the deceased or its presence otherwise symbolised, pars pro toto, by placing chariot related artefacts such as jokes, pairs of bridle-bits, lynch pins or miniature wagon. In the case of Macedonian necropolises it was noticed that the carts used for transporting the dead in the funeral procession to the grave, after the deceased was exposed and mourned, are not dedicated carts solely for this purpose but the same one used in everyday life. However, the wagons are not drawn by draft animals (oxes or mules) but rather by horses, preferred for ritual ceremonies. Miniature clay horses were placed together with the cart in several tombs from Sindos and Archontiko suggesting their importance in this ritual ${ }^{56}$. An interesting grave, no. 59 in Sindos necropolis, is represented by the grave of a young boy dated between 530-520 BC, in which was deposited a miniature chariot harnessed by two clay horses and accompanied by a third riding horse. The inventory of the grave comprises also several interesting pieces relating to the social status of the boy, represented as a warrior despite being a juvenile, having a helmet of „Illyrien” type, a sword, and two spear heads. Furthermore,

${ }^{54}$ GERGOVA 2006, 51-56.

55 THEODOSIEV 2000, 190; DEL SOCORRO 2017, 188.

${ }^{56}$ DEL SOCORRO 2017, 188 other artefacts are related with the funerary banquet such as bronze vessels or clay, but also a miniature table and chair and obeloi and finally several recipients for perfume or unguents $s^{57}$. It seems that the assemblage of miniature offerings are part of a specific complex of models of tables and chairs, of chariots loaded with wood, of two-wheeled chariots in which horses modelled from clay are harnessed and accompanied by a third riding horse, and of platforms for firewood and skewers depicting ritual scenes ${ }^{58}$.

In association with miniature cart offerings, related with the funerary banquet, several types of vessel for wine rituals have been placed. In a few situations the handles of the vessels are decorated with water-birds as it is at Pydna, Archontiko and Trebenishte (opš. Ohrid/MK), while in a grave in Trebenishte a tripod is decorated with bird heads. The presence of aquatic birds is frequent in Macedonian graves and, with few exceptions, all are associated also with miniature carts and other miniature objects like the chairs, tables or obeloi. These birds made of clay are represented either independently, or accompanying a personage, sitting on its right hand. However, not all of the bird representations are water-birds but their interpretation in relation with funerary practice is rather similar. The migration of aquatic birds is associated with the cycle of life in various cultures from the centre of Europe and east towards to Asia Minor. The characters holding a bird are associated with similar representation of certain Attic funerary monuments from the Archaic period, the bird being a perfect companion for travel to the Chthonic underworld ${ }^{59}$. It should be mentioned

\footnotetext{
7 VOKTOPOULOU/DELOPOULOS-VOKTOPOULOU 1996, 114-118.

${ }^{58}$ GERGOVA 2006, 51

59 DEL SOCORRO 2017, 172.
} 
here that the chariot from Vari has on top a representation of a bird ${ }^{60}$.

Furthermore, this could be placed in relation to water-birds protomes discovered in the Dacian fortress from Costești-Cetățuie (jud. Hunedoara/RO) (Fig. 8/e-f) and Sarmizegetusa Regia - Grădiștea de Munte (jud. Hunedoara/ $\mathrm{RO})^{61}$ but, as well, with the interpretation as „solar wagon” of Dacian wagon models ${ }^{62}$. In this idea, despite a big chronological gap, these artefacts are very similar in shape and size with the ones from the Bujoru chariot especially, and also with the ones from Orăștie. These Dacian protomes were interpreted as metal vase handles, but alternatively as attachments on a wagon ${ }^{63}$.

The association of chariot or wheel, water birds and vessel could be considered in the case of the main tomb of Cugir (jud. Alba/RO) Dacian tumulus. Here, the deceased was cremated on a life-size chariot, while the presence of the vessel and the water birds is suggested by a bronze situla with water-birds shaped handle (Fig. 8/a), placed in association with the banquet ${ }^{64}$. Similar graves are known as well in the case of the rich inventory of grave 7 of San Maria di Zevio "Lazisetta” (prov. Verona/IT) ${ }^{65}$, where several objects used for banqueting have water-birds handles. The same could be considered in the case of a presumed wagon grave from Visagio, Ciringhelli (prov. Verona/IT) ${ }^{66}$, but also the grave from Verna (dép. Isére/F) ${ }^{67}$.

The presence of vessel handles with water-birds is attested as well in some of the sites where fragmentary wheels-model were found, but not in the same archaeological context. This is the case for a situla handle (Fig. 8/b) discovered at Luncani-Piatra Roșie fortress by treasure hunters ${ }^{68}$. The context of discovery is unknown due to illegal detection, but it worth mention that few chariot elements and other military and harness pieces (a spear head, a bit, a terret ring) were part of the recovered artefacts, and one may see a part of a funerary inventory without any certitude whatsoever. From old excavations at Sighișoara-Wiettenberg site, an iron handle with water-birds was discovered, but similarly the archaeological context is unknown ${ }^{69}$. Similar handles were also found at Costești-„Cetățuie”70 (Fig. 8/c), Căpâlna (jud. Alba/RO) ${ }^{71}$, Tilișca (jud. Sibiu/RO) ${ }^{72}$. The vessels (mostly situlae) with handles with water-birds originate either from the Italic Peninsula, were produced in the Balkans and/or the eastern Mediterranean, but also could be produced by local or travelling craftsmen ${ }^{73}$. Their

\footnotetext{
60 VERMEULE 1979, 18.

${ }^{61}$ IAROSLAVSCHI 1997, 511-519.

62 BICHIR 1982, 154.

${ }^{63}$ IAROSLAVSCHI 1997, 513; FLOREA 2015, 18-20; FLOREA/CRISTESCU 2016, 146, Fig. 12.

${ }^{64}$ CRIȘAN 1980, 82-83; POPA 2004, 100; RUSTOIU 2002, 52; RUSTOIU 2015, 359-360; POPA 2011, 326, Pl. 151/1-3; TELEAGĂ et alii 2014, 314-321.

${ }^{65}$ BOLLA/CASTOLDI 2016, 121-155; Cf. BOŽIČ 2017.

${ }^{66}$ Cf. BOŽIČ 2017

67 PERIN/SCHÖNFELDER 2003.

${ }^{68}$ FRENCZ/BODO 2000, 175, Pl. II/1.

${ }^{69}$ HOREDT/SERAPHIN 1971, 84, Abb. 67/4; ANDRIȚIU/RUSTOIU 1997, 106. Fig. 114/1.

${ }^{70}$ GLODARIU 1974,234,Pl.XLV/B10/11;MATEESCU-SUCIU/GHEORGHIU/

GĂZDAC 2016, 118, Fig. 10.

${ }^{71}$ GLODARIU/MOGA 1989, 103, Fig. 87/4,8.

${ }_{72}$ LUPU 1989, 79, Pl. 22/18.

${ }^{73}$ EGRI/BERECKI 2015, 134.
}

utility is related with wine consumption and their presence in the funerary context is connected with the funerary rituals and banquets. The vessels with water-birds handles discovered in graves together with chariot elements were most likely purchased for this funeral ritual, representing a manifestation that originates in earlier periods, even though the meaning of this was maybe lost, or known only by the ones whom officiated the funerary service ${ }^{74}$. An argument for this interpretation is represented in the so-called "second warrior grave" from Sesto Calende (prov. Varese/IT), dated between $7^{\text {th }}-6^{\text {th }}$ century $\mathrm{BC}^{75}$. The inventory of this grave represents a rare case comprising the deposition of both twowheeled life-size chariot and a Kesselwagen. The inventory comprises warrior equipment (bronze helmet, sword handle, spear head, bronze greave), harness elements but also some interesting bronze and pottery vessels associated with the presence of water-birds. An interesting pottery artefact is an orthomorphic (duck) guttus, used most likely in the funerary ceremony for libation ${ }^{76}$. The presence of water-birds receptacles is attested later in a few graves of Macedonian necropolises, in Sindos and Arkontiko ${ }^{77}$. The bronze vessels of the Sesto Calende warrior grave comprise of a situla of Kurd type, another situla, a cup, a bowl, a glass, and a cista a cordoni $i^{78}$. Within the inventory was also found a handle of the usual type of bronze rod decorated with a twist and with the stylized swan's head ends, most likely belonging to the second situla ${ }^{79}$. The presence of this kind of situla handle with water-bird terminals represents a stylized representation of the antithetic water-birds, the so common symbol with roots in Urnfield cultural manifestation, depicted also on the figurative elements of pairs of water-birds and solar symbols present on situlae or stamnoi of Hajdubőszőrmény type, a symbol that was transmitted later in different forms.

Coming back to miniature carts from Macedonian graves, presented above was the grave comprising of a miniature iron chariot and three clay horses, two of them harnessed with the third one for riding ${ }^{80}$. In other graves, miniature clay horses were placed as well, but only one or two. The miniature carts placed in graves represent the life-size chariot used in the funerary process, while the miniature clay horses could represent the sacrificed horses placed together with their owner as in the case of the Thracian sumptuous tumulus. As was argued above, there can be seen a powerful influence given from the Greeks on the one hand, and Persian on the other, associated with Thracian populations in the territory of modern Macedonia and Bulgaria, that affected the ways of living, the mentality, architecture and funerary practice of the $6^{\text {th }}-5^{\text {th }}$ century $B C^{81}$. After the Persian wars from the beginning of the $5^{\text {th }}$ century $\mathrm{BC}$ there followed a retreat and the disappearance of Persian hegemony from Europe, while the Macedonians, Athenians and other Greek cities were disputing their hegemony in the Balkan Peninsula. The Greek colonisation on the western

\footnotetext{
${ }^{7}$ DIMA/BORANGIC 2018, 29.

5 DE MARINIS 2009, 163-203.

6 DE MARINIS 2009, 173-174.

77 DEL SOCORRO 2017, 171-173.

78 DE MARINIS 2009, 176.

79 DE MARINIS 2009, 179.

${ }^{80}$ VOKTOPOULOU 1996, 114-118.

81 THEODOSIEV 2000, 191.
} 

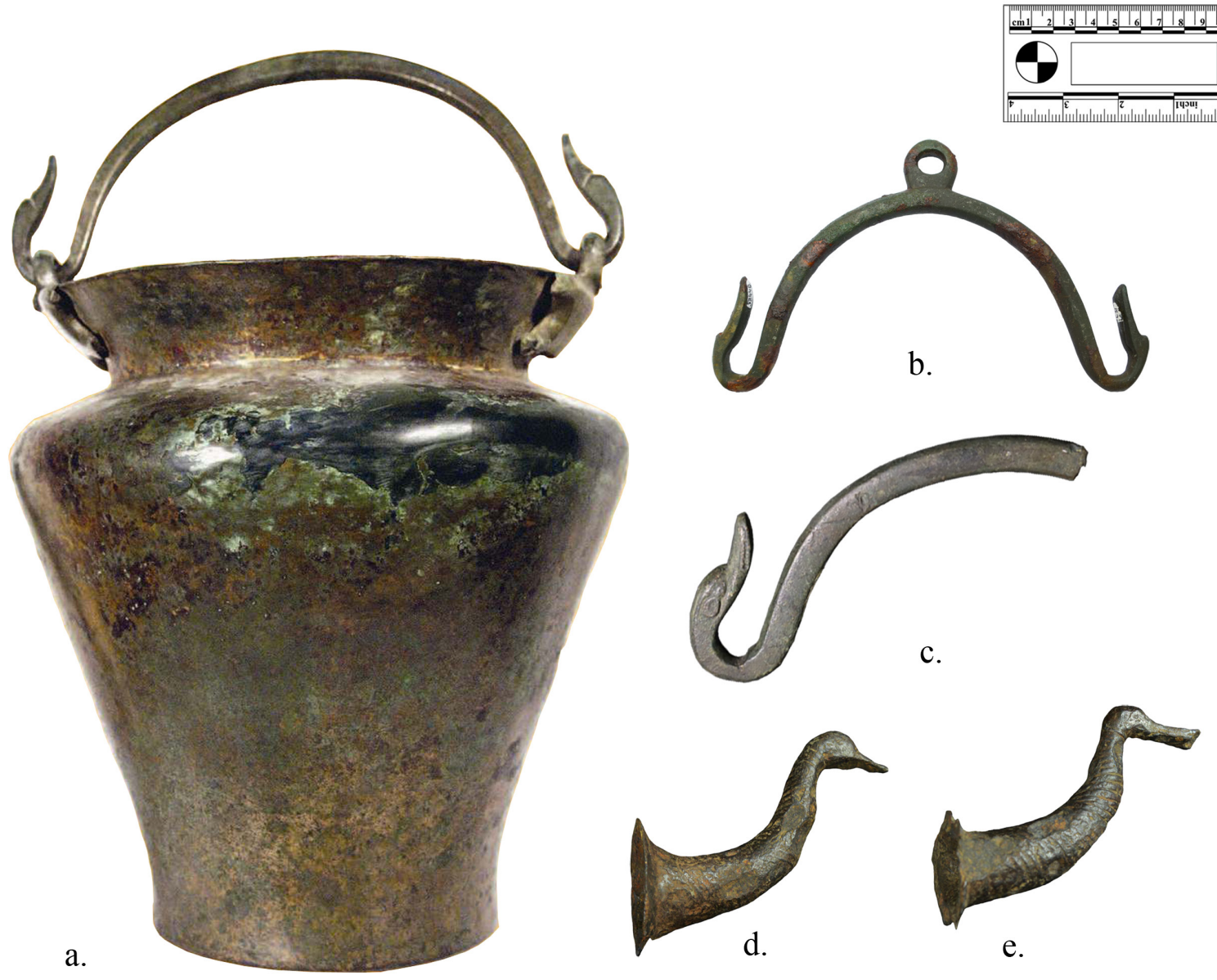

Fig. 8. Situlae handles with water-birds: a. Cugir (after MOGA/PLANTOS 2017, 20); b. Sighișoara - Wietenberg (photo N. Tescula); c. Luncani-Piatra Roșie (photo C. Dima); d. Costești-Cetățuie (after MATEESCU-SUCIU/GHEORGHIU/GĂZDAC 2016); e.-f. waterbirds protomes discovered in dacian fortification of Costești-Cetățuie (after FLOREA 2015).

coast of Black Sea could not have been successful without interaction with the Odrysian Kingdom and as well with the Scythian dynasty. The presence of Greek colonies, and as well the Thracian and Scythian tribes, resulted in a series of contacts and influences visible in cultural manifestations, funerary practice and art. A Persian influence through the Greeks was at the same time considered in the development of Thracian toreutics in the $4^{\text {th }}$ century BC that evolved independently from Scythian art, while other authors suggest that there are several elements to suggest Scythian influence in what is believed to be solely Thracian $\operatorname{art}^{82}$. There was also discussion regarding the Scythian presence and influence in the of the fastidious grave from Agighiol (jud. Tulcea/RO) ${ }^{83}$. Regardless of the influences on toreutics, the funerary ritual of this tomb is an exceptional phenomenon. Excluding the sumptuous military equipment, adornments and funerary banquet vessels in the grave were deposited three sacrificed horses along with their harness. The sacrifice and the offering of horses represents a phenomenon well attested in the Scythian rich graves from the north of the Black See area but also in the Thracian graves from south of the Danube. Has been noted from the beginning of the $4^{\text {th }}$ century that miniature chariots placed as grave goods begun to disappear from Macedonian tombs and this could

82 TELEAGĂ 2014, 295-318.

83 TELEAGĂ 2010, 78-85; 2014, 295-318; CONSTANTINESCU et alii 2014, 645-666. be placed in connection with some changes in funerary customs. Especially following the rise of the Macedonian kings Philip II, Alexander III the Great and their successors, the Diadochi, the characteristic tomb form in Macedonia, Thessaly and the area of Thracia between the Danube and the Black Sea coast, is a built tomb with a long dromos ending in a rectangular chamber, both roofed with a barrel-vault, although the cist graves continued at the same time ${ }^{84}$. In the upper Vardar River valley in the same period there can be noted a Macedonian influence and the occurrence of wellbuilt tombs considered representative of elite burials of tribal societies. The Greeks and Macedonians influence not only the funeral architecture, but also the funerary ritual through which Thracian tribal elites express their political power and religious authority in different ways. The sacrifice and the commemorative games organised in honour of the dead show that Thracian rulers and nobles were heroized in the Greek manner ${ }^{85}$. A special case mentioned above is in relation with that of the horse sacrifice and the burial of the chariot as well. The presence of miniature clay and iron or bronze carts in Macedonian necropolises clearly expressed in a symbolic manner the horse funerary sacrifice that probably carried the funerary cart in the process of ekphora. Sacrificed horses are present in few rich Macedonian graves in Sindos ${ }^{86}$

\footnotetext{
${ }^{84}$ D`ANGELO 2010, 57-68; GUŠTIN/KUZMAN 2016, 314.

85 THEODOSSIEV 2000b, 435-447.

86 ANTIKAS 2008, 24-27.
} 
and Vergina ${ }^{87}$ and their rarity shows that such custom was not for everyone and only few had the honour of being buried with horse or other animal sacrifice.

The presence of two harnessed clay miniature horses and a third saddled one seems to be a pattern for few graves with sacrificed horses present as well in Thracian tumuli, though this cannot be generalised, several graves having just a pair of sacrificed horses, or just one. For instance, the rich tumulus, Mogilaskata Mogila from Vratsa/BG has three stone-built burial constructions. The most important was placed in the centre of the tumulus, and the funerary procession of ekphora was symbolised by a wagon with twosacrificed horses and another saddle-horse ${ }^{88}$. The same ritual of ekphora was symbolised by a wagon with two horses and another horse, all sacrificed, placed in the front of the tomb entrance from Zhaba Mogila tumulus, near Strelcha (Obl. Pazardzhik/BG) ${ }^{89}$. All of these examples show common practices of Macedonian, Thracian tribes and Scytians tribes, visible throughout funerary practice as proof of their influences that works in both directions and builds a common aristocratic ideology present in the area of Balkans in the $5^{\text {th }}$-3th century BC.

In Dacian milieu the horse sacrifice with or without chariot is attested in the case of the Cugir tumulus ${ }^{90}$ and most likely in the funerary context from Călan ${ }^{91}$ (jud. Hunedoara/ RO), both having similarities with the three horse sacrifice attested for the Thracian tumulus of $4^{\text {th }}-3^{\text {rd }}$ century BC. This similar funerary practice represents, most likely, a result of the perpetuation of certain ideas and concepts through time that could be traced back to the warriors belonging to the Padea-Panagjurski Kolonii group. This group of warriors took over a series of elements of aristocratic ideology as tumulus burial, equestrian heroization, iconographic and symbolic motifs and reinterpreted this in their manner, expressing their identity by new symbolic means ${ }^{92}$.

Summarise these discussions on the subject of model-wagons attested in Dacian milieu, a few conclusions must be drawn. The rise of the Dacian civilisation is linked to the appearance of the new warrior ideology in the area of north-western and western Balkan Peninsula. This warrior group evolved, reinterpreting in their own way the ideology of aristocratic elites of Macedonians and Thracian of the $5^{\text {th }}$ $3^{\text {rd }}$ century BC. The horse sacrifice and the chariot (life-size, pars pro toto or miniaturised) in the burials of the PadeaPanagjurski Kolonii group is reserved for only few members of aristocracy and clearly originates in the funerary customs and practice of earlier Thracian tumuli influenced on one side by a Celtic presence and on the other side by Greeks. The miniature carts found in the Macedonian graves of $6^{\text {th }}-4^{\text {th }}$ century BC symbolise in the first place the funerary procession of ekphora, a ritual depicted later on Thracian funerary monuments, but also in the burial of the life-size chariot and sacrificed pair of horses and the third saddlehorse. Although, no miniature carts or wagon-models have

\footnotetext{
87 ANTIKAS 2002, 46-49.

88 THEODOSSIEV 2000b, 435-447.

89 THEODOSSIEV 2000b, 435-447

${ }^{90}$ CRIȘAN 1980, 82-83; POPA 2004, 100; RUSTOIU 2002, 52; RUSTOIU 2015, 359-360; POPA 2011, 326, Pl. 151/1-3; TELEAGĂ et alii 2014, 314-321.

${ }^{91}$ RUSTOIU/SÎRBU/FERENCZ 2002, 111-127.

${ }_{92}$ RUSTOIU 2015, 355.
}

yet been found in the Thracian necropolises, the concept was preserved by the deposition of life-size ceremonial carts and later transmitted to Dacian aristocracy.

The model-wagon and model-wagons fragments from Dacian milieu do not have clear archaeological contexts and can likely be placed in relation either with a votive deposition or a funerary one. Their origins can be traced back through time and are linked with Thracian funerary manifestation and further with Macedonian funerary miniaturised cart deposition up to the funerary expression of Early Iron Age and Urnfield Kesselwagen depositions.

\section{REFERENCES}

ANDRITOIU/RUSTOIU 1997

Andriţoiu, I./Rustoiu, A., Sighişoara-Wietenberg. Descoperirile preistorice şi aşezarea dacică (Bucureşti: Vavila Edinf).

ANTIKAS 2002

Antikas, T.G., Horses and Heroes in the Tomb of Philip II, Minerva magazine 13/1, 46-49.

\section{ANTIKAS 2008}

Antikas, T. G., They didn't shoot horses: fracture management in a horse of the 5th century BCE from Sindos, Central Macedonia, Greece, Veterinarija ir Zootechnika 43/64, 21-27.

BICHIR 1982

Bichir, Gh., Manifestări cu caracter magic și de cult la getodacii din Muntenia, Thraco-Dacica 3, 153-159.

BOLLA/CASTOLDI 2016

Bolla, M./Castoldi M., I recipienti di bronzo in Italia settentrionale tra IV e I secolo a.C. e il caso del territorio veronese, Arheološki vestnik 67, 121-175.

BOUZEK 1974

Bouzek, J., Graeco-Macedonian Bronzes (Analysis and Chronology) (Prague: Universita Karlova).

BOUZEK/ONDŘEJOVÁ 1988

Bouzek, J. /Ondřejová, I., Sindos-Trebenishte-Duvanli. Interrelations between Thrace, Macedonia, and Greece in the 6th and 5th centuries BC, Mediterranean Archaeology 1, 84-94.

BOŽIČ 2017

Božič, D., A new wagon grave from Late La Tène? Proceedings of the 18th International Conference: The Celts (Plumlov Moravia). (DOI: 10.13140/RG.2.2.16672.99844) (in progress).

CHRYSOSTOMOU/CHRYSOSTOMOU 2012

Chrysostomou, P./Chrysostomou, A., The Lady of Archontiko. In: Stampolidis, N.C./Giannopoulou, M. (eds.), 'Princesses' of the Mediterranean in the Dawn of History [exhibition catalogue Athens] (Athens: Museum of Cycladic Art), 367-387.

CONSTANTINESCU et alii 2014

Constantinescu, B./Stan, D./Babeş, M./Nicolae, C.I.,Analiza compozițională a tezaurelor de argint geto-dacice de la Agighiol, Peretu, Craiova și Poroina. In: Forțiu, S. Cântar, M. (eds.), Arheovest II. In honorem Gheorghe Lazarovici, Interdisciplinaritate în arheologie, Timişoara, 6 decembrie 2014 (Szeged), 645-666.

CRIȘAN 1980

Crișan, I. H., Necropola dacică de la Cugir (jud. Alba). (Considerații preliminare), Apulum 18, 81-87.

D ANGELO 2010

D`Angelo, B., The evolution of the Macedonian tomb: Helenistic funerary architecture revisited, Patrimonium 7-8, 57-68. 


\section{DAICOVICIU 1954}

Daicoviciu, C., Cetatea dacică de la Piatra Roșie. Monografie arheologică (București: Editura Academiei Republicii Populare Romîne).

DE MARINIS 2009

de Marinis, R. C., Sesto Calende, la seconda tomba di guerriero. In: de Marinis, R.C./Massa, S./Pizzo. M. (eds.), Alle origini di Varese e del suo territorio. Alle origini di Varese e del suo territorio: le collezioni del sistema archeologico provinciale (Roma: «L’Erma» di Bretschneider), 162-203.

DEL SOCORRO 2013

del Socorro, N., Miniature objects from the Archaic Tombs of Macedonia, Haemus 2, 53-60.

DEL SOCORRO 2017

del Socorro, N., Les rites funéraires dans le royaume téménide et ses environs à la période archaïque [unpubl. Diss. Univ. Paris Nanterre].

\section{DIMA 2020}

Dima, C., Late Iron Age wagon-models. Where they come from and where they go?, Archäologisches Korrespondenzblatt $50 / 1$ (in print).

DIMA/BORANGIC 2018

Dima, C./Borangic, C., Wagon-Models from the Second Iron Age. Journey to the Outer World or Gifts for the Gods? Archaeologia Bulgarica 24/2, 15-32.

EGRI/BERECKI 2015

Egri, M./Berecki, S., Italy, Macedonia and Dacia - networks of interaction in the 2nd - 1st centuries BC. In: Guštin, M./David, W. (eds.), The Clash of Cultures? The Celts and the Macedonian World [Schriften des Kelten-Römer-Museums 9] (Manching: KASTNER AG - das Medienhaus), 129-136.

FERENCZ/BODO 2000

Ferencz, I. V./Bodó, C., Noi piese descoperite la Piatra Roșie (județul Hunedoara), Sargetia 28-29/1, 169-181.

FLOREA 2015

G. Florea, Protome de păsări acvatice. In: Mateescu R./Gheorgiu G. (eds.), Sarmizegetusa Regia. Cromatică și decor în antichitatea dacică. Catalog de expoziție (Cluj-Napoca 2015), 18-20.

FLOREA/CRISTESCU 2016

Florea, G./Cristescu, C., Artă, identitate și imaginar / Art, identity and imaginary. In: Neamţu, C./Florea, G./ Gheorghiu, G., Bodó, C. (eds.), Când viața cotidiană antică devine patrimoniu UNESCO - Incursiuni dacice în spațiul virtual (Cluj-Napoca: Editura Only One), 141-163.

GERGOVA 2006

Gergova, D., The eternity of the Burial Rite. The throne and the sitting Deceased, Acta Terrae Septemcastrensis 5/1, Special Number, 51-62.

GLODARIU/MOGA 1989

Glodariu, I./Moga, V., Cetatea dacică de la Căpâlna (București: Editura Științifică și Enciclopedică).

\section{GLODARIU 1974}

Glodariu, I., Relații comerciale ale Daciei cu lumea elenistică și romană (Cluj-Napoca: Dacia).

\section{GUŠTIN/KUZMAN 2016}

Guštin, M./Kuzman, P., The Elitte. The Upper Vardar River Region in the Period from Reign of Philip II Macedon until the Reign of Diadochi. In:V. Sîrbu et alii (eds.), Funerary practices during the Bronze and Iron ages in central and southeast Europe. Proceedings of the 14th International Colloquium of Funerary Archaeology in Čačak, Serbia, 24th - 27th September 2015 (Beograd-Čačak: Faculty of philosophy-National museum) 313-332.

HOREDT/SERAPHIN 1971

Horedt, K./Seraphin, C., Die prähistorische Ansiedlung auf dem Wietenberg bei Sighişoara-Schässburg (Bonn: R. Habelt).

\section{HOREDT 1964}

Horedt, K., Die Verwendung des Eisens in Rumänien bis in das 6. Jahrhundert v.u.Z. Dacia N.S. 8, 119-132.

IAROSLAVSCHI 1997

Iaroslavschi, E., Vases daciques en fer aux anses en forme d`oiseaux, Acta Musei Napocensis 34/1, 511-519.

IGNATIODOU 2012

Ignatiodou, D., The Sindos Priestess. In: Stampolidis, N.C./ Giannopoulou, M. (eds.), 'Princesses` of the Mediterranean in the Dawn of History [exhibition catalogue Athens] (Athens: Museum of Cycladic Art), 388-411.

KIERNAN 2009

Kernan, P., Miniature votive offerings in the Roman NorthWest (Mainz: Franz Philipp Rutzen Verlag).

KOTTARIDI 2004

Kottaridi, A., The Lady of Aigai. In: Pandermalis, D. (ed.), Alexander the Great: Treasures from an Epic Era of Hellenism. Exhibition catalogue New York (New York: Alexander S. Onassis Public Benefit Foundation), 139-147.

KOTTARIDI 2011

Kottaridi, A., Queens, princesses and high priestesses: the role of women at the Macedonian court. In: Kottaridi, A. (ed.), Heracles to Alexander: Treasures from the Royal Capital of Macedon, a Hellenic Kingdom in the Age of Democracy. Exhibition catalogue (Oxford: Ashmolean Museum), 93-126.

LUCA et alii 2013

Luca, S. A./Georgescu, A./Natea, G.V./Teodorescu, R. M./Urduzia, C./Munteanu, C. I./Palaghie, V./Luca, A., Cercetarea preventivă. Provocarea arheologică a zilelor noastre (Sibiu: Muzeul National Brukenthal).

LUPU 1989

Lupu, A., Tilișca. Așezările arheologice de pe Cățănaș (București: Editura Științifică și Enciclopedică).

MATEESCU-SUCIU/GHEORGHIU/GÄZDAC 2016

Mateescu-Suciu, L./Gheorghiu, G./Găzdac, C., Trade. In: Neamţu, C./Florea, G./Gheorghiu, G./Bodó, C. (eds.), Când viața cotidiană antică devine patrimoniu UNESCO - Incursiuni dacice în spațiul virtual (Cluj-Napoca: Editura Only One), 99128.

MOGA/PLANTOS 2007

Moga, V./Plantos, C. (eds.), Interferențe culturale în Dacia Preromană. Importuri și influențe greco-romane în sud-vestul Transilvaniei. Exhibition catalogue Alba Iulia (Alba Iulia: Editura Altip).

MOSCALU/BEDA 1988

Moscalu, E./Beda, C., Bujoru. Un tumul cu car - cazan votiv aparţinând culturii Basarabi, Thraco-Dacica 9/1-2, 23-48.

NATEA 2016

Natea, Gh. V., Locuințe aristocratice în Dacia sec. I t.. Chr. - Id. Chr. (Sibiu: Editura Muzeului Național Brukenthal).

PARE 1989

Pare, C. F. E., From Dupljaja to Delphi: the ceremonial use of the wagon in later prehistory, Antiquity 63/238, 80-100.

PARE 1992

Pare, C. F. E., Wagons and Wagon-Graves of the Early Iron Age in Central Europe (Oxford: Oxford Committee for Archaeology).

PERIN/SCHÖNFELDER 2003

Perin, F./Schönfelder, M., La tombe à char de Verna (Isère) POPA 2004 (Lyon: Alpara)

Popa, C. I., Descoperiri dacice pe valea Cugirului. In: Pescaru, A./Ferencz, I.V. (eds.), Daco-Geții. 80 de ani de cercetări arheologice sistematice la cetăţile dacice din Munţii Orăştiei (Deva: Muzeul Civilizaţiei Dacice şi Romane), 83166. 
POPA 2011

Popa, C. I., Valea Cugirului din preistorie până în zorii epocii moderne (Cluj-Napoca: Mega).

RUSTOIU 2002

Rustoiu A., Războinici și artizani de prestigiu în Dacia Preromană (Cluj-Napoca: Nereamia Napocae).

RUSTOIU 2015

Rustoiu, A., Civilian and funerary space in the dacian fortified settlement at Cugir. In: Forțiu, S./Stavilă, A., (eds.), In Memoriam Florin Medeleț. Interdisciplinaritate în Arheologie și Istorie. Timișoara, 28 noiembrie 2015 [ArheoVest 3/1] (Szeged: JatePress Kiadó), 349-367.

RUSTOIU/BERECKI 2012

Rustou, A./Berecki, S., 'Thracian` warriors in Transylvania at the beginning of the Late Iron Age. The grave with Chalcidian helmet from Ocna Sibiului. In: Berecki, S. (ed.), Iron age rites and rituals in the Carpathian basin : proceedings of the international colloquium from Târgu Mureș, 9-7 October 2011 (Târgu Mureș), 161-181.

RUSTOIU/SÎRBU/FERENCZ 2002

Rustoiu, A./Sîrbu, V./Ferencz, I. V., Mormântul tumular dacic de la Călan (jud. Huneoara), Sargetia 30, 111-127.

\section{SCHÖNFELDER 2000}

M. Schönfelder, Das spätkeltische wagengrab von Boé (Dép. Lot-et-Garonne) - Studien zu wagen und wagengräbern der jüngeren latènezeit, (diss. Univ. Marburg).

SCHUSTER 2007

Schuster, C., Transportul terestru în preistorie, cu privire specială la Dunărea de Jos (Târgoviște: Editura Cetatea de Scaun).

TELEAGĂ 2010

Teleagă, E., Die Prunkgräber aus Agighiol und Vraca. In: Amazonen - Geheimnisvolle Kriegerinnen [exhibition catalogue Speyer] (München: Trikont Verlag), 78-85.

\section{TELEAGĂ 2014}

Teleagă, E., Pecetea lui Skyles şi tumulii fastuoşi de la Agighiol şi Cugir. Omisiune şi falsificare în fondarea mitului „strămoşilor”românilor, geto-dacii, Studii și cercetări de istorie veche și arheologie 65/3-4, 295-318.

\section{TELEAGĂ et alii 2014}

Teleagă, E./Bălășescu, A./Soficaru, A./Schoch, W., Die Scheiterhaufen aus Cugir und Tarinci. Ein Beitrag zu den Bestattungssitten der Balkanhalbinsel und des vorrömischen Dakiens in der Spätlatènezeit, Praehistorische Zeitschrift 89/2, 305-336.

THEODOSIEV 2000

Theodosiev, N., The dead with golden faces. II Other evidence and connection. Oxford Journal of Archaeology 19/2, 175-210.

VENDIKOV/GHERASIMOV 1973

Venedikov, I./Gerasimov, T., Trakijskoto izkustvo (Sofia: Izd. Bulgarski khudozhnik).

VERMEULE 1979

Vermeule, E., Aspects of death in Early Greek art and poetry (Berkeley-Los Angeles-London: University of California Press).

VOKTOPOULOU/DELOPOULOS-VOKTOPOULOU 1996

Vokotopoulou. J./Delopoulos-Voktopoulou, J., Guide du Musée Archéologique de Thessalonique (Athènes: Kapon).

VON WOLFGANG 2014

von Wolfgang, D., Makedonen und Kelten am Ohrid-See ein Zusammenprall der Kulturen?, Bayerische Archäologie 4, 46-51.

VULPE 2001

Vulpe, Al., Ältere Eisenzeit/Späthallstattzeit (8. - 5. Jahrhundert v. Chr.). In: Rotea, M./Bader, T., Thraker und Kelten beidseits der Karpaten. Sonderausstelung September 2000 - Aprilie 2001 (Eberdingen: Keltenmuseum Hochdorf/ Enz), 42-51. 